\title{
Effect of Alloying Elements in Melt Spun Mg-alloys for Hydrogen Storage
}

\author{
Silvia Rozenberg ${ }^{a *}$, Fabiana Saporiti $^{a}$, Julien Lang ${ }^{b}$, Fernando Audebert ${ }^{a, c}$, Pablo Botta ${ }^{d}$, Mihai Stoica ${ }^{e}$, \\ Jacques Huot ${ }^{b}$, Jürgen Eckertf \\ ${ }^{a}$ Advanced Materials Group, Instituto de Tecnologías y Ciencias de la Ingeniería "Hilario Fernández \\ Long" - INTECIN, Faculty of Engineering, University of Buenos Aires, Paseo Colón 850, Ciudad de \\ Buenos Aires, C1063ACV, Argentina \\ ${ }^{b}$ Institut de recherche sur l'hydrogène, Université du Québec à Trois-Rivières, 3351 des Forges, Trois- \\ Rivières, Québec, G9A-5H7, Canada \\ ${ }^{c}$ Department of Mechanical Engineering and Mathematical Science, Oxford Brookes University, Oxford, \\ Wheatley Campus, OX33 1HX, Oxford, United Kingdom \\ ${ }^{d}$ Institute of Research in Materials Science and Technology - INTEMA, Faculty of Engineering, University \\ of Mar del Plata, Buenos Aires, Av. Juan B. Justo, 4302, Mar del Plata, 7600, Buenos Aires, Argentina \\ ${ }^{e}$ Leibniz Institute for Solid State and Materials Research Dresden - IFW Dresden, Leibniz Institute, \\ Helmholtzstraße, 20, 01069, Dresden, Germany \\ ${ }^{f}$ Erich Schmid Institute of Materials Science, Austrian Academy of Sciences and Department Materials \\ Physics, Montanuniversität Leoben, Jahnstraße 12, A-8700 Leoben, Austria
}

Received: January 21, 2016; Revised:May 23, 2016; Accepted: June 25, 2016

In this paper we report the effect of alloying elements on hydrogen storage properties of meltspun $\mathrm{Mg}$-based alloys. The base alloys $\mathrm{Mg}_{90} \mathrm{Si}_{10}, \mathrm{Mg}_{90} \mathrm{Cu}_{10}, \mathrm{Mg}_{65} \mathrm{Cu}_{35}$ (at\%) were studied. We also investigated the effect of rare earths (using MM: mischmetal) and $\mathrm{Al}$ in $\mathrm{Mg}_{65} \mathrm{Cu}_{25} \mathrm{Al}_{10}, \mathrm{Mg}_{65} \mathrm{Cu}_{25} \mathrm{MM}_{10}$ and $\mathrm{Mg}_{65} \mathrm{Cu}_{10} \mathrm{Al}_{15} \mathrm{MM}_{10}$ alloys. All the melt-spun alloys without $\mathrm{MM}$ show a crystalline structure, and the $\mathrm{Mg}_{65} \mathrm{Cu}_{25} \mathrm{MM}_{10}$ and $\mathrm{Mg}_{65} \mathrm{Cu}_{10} \mathrm{Al}_{15} \mathrm{MM}_{10}$ alloys showed an amorphous and partially amorphous structure respectively. At $350^{\circ} \mathrm{C}$ all the alloys had a crystalline structure during the hydrogen absorption-desorption tests. It was observed that $\mathrm{Si}$ and $\mathrm{Cu}$ in the binaries alloys hindered completely the activation of the hydrogen absorption. The partial substitution of $\mathrm{Cu}$ by $\mathrm{MM}$ or $\mathrm{Al}$ allowed activation. The combined substitution of $\mathrm{Cu}$ by $\mathrm{MM}$ and $\mathrm{Al}$ showed the best results with the fastest absorption and desorption kinetics, which suggests that this combination can be used for new Mg-alloys to improve hydrogen storage properties.

Keywords: Hydrogen storage, Mg based alloy, Rapid solidification, Nanomaterials

\section{Introduction}

Hydrogen is a promising clean energy carrier with great potential for mobile and stationary applications replacing petroleum fuels ${ }^{1}$. There are many technological and economic problems to be solved to extend industrial applications of hydrogen as fuel: the production, storage and energy conversion systems. Hydrogen storage is clearly one of the key challenges in developing hydrogen economy. Three basic hydrogen storage methods are considered, which at the present are: (i) pressurized gas, (ii) cryogenic liquid, (iii) solid fuel as chemical or physical combination with materials, such as metal hydrides and complex hydrides ${ }^{2}$. Each of these options possesses attractive attributes for hydrogen storage ${ }^{3}$. Mg-base alloys have great potential for solid-state hydrogen storage, because $\mathrm{Mg}$ has high hydrogen absorption capacity near to $7.6 \mathrm{wt} \% \mathrm{H}$ for $\mathrm{MgH}_{2}$, more than most other metal hydrides, good reversibility, low specific weight, low cost and a comparatively high availability in the earth's crust ${ }^{1,4}$. First works in this area were made by Reilly and Wiswall ${ }^{5,6}$ on $\mathrm{Mg}-\mathrm{Cu}-\mathrm{H}$ and $\mathrm{Mg}-\mathrm{Ni}-\mathrm{H}$ systems. However, the hydrogen absorption-desorption kinetics are

* e-mail: silvia.rozenberg@gmail.com low and need high temperature (from $300^{\circ} \mathrm{C}$ to $400^{\circ} \mathrm{C}$ ) due to the large formation enthalpy of the $\mathrm{Mg}$ hydride and diffusion properties. Possible ways to improve the hydrogen absorption-desorption kinetics are alloying $\mathrm{Mg}$ to modify the crystal structure of the hydrides by addition of transition metals, metal oxides or rare earths $s^{7-15}$, reducing the grain size by alloying elements, mechanical deformation or rapid solidification. In recent years the absorption-desorption of hydrogen in $\mathrm{Mg}$ alloys produced by unconventional methods have been investigated ${ }^{16-18}$. It was observed that the reaction kinetics are improved when the Mg based materials have nanometric structures ${ }^{19,20}$. The addition of rare earths increases the kinetics of absorption and/or desorption in $\mathrm{Mg}-\mathrm{Ni}$ and $\mathrm{Mg}-\mathrm{Cu}-\mathrm{Ni}$ alloys ${ }^{21,22}$. It was also observed that absorption-desorption kinetics are favorable in $\mathrm{Mg}$ - $\mathrm{Al}$ alloys containing amorphous or nanostructured phases when it is compared to pure $\mathrm{Mg}^{23}$. In general, absorption-desorption kinetics of alloys with amorphous phases and/or nanocrystalline microstructure are higher at lower temperature when compared to micro-crystalline structures ${ }^{24}$.

Amorphous and/or nano-structured Mg alloys can be achieved by rapid solidification or mechanical grinding processes. In general, in these alloys the crystallization 
temperature of the amorphous phase is lower than the activation temperature of the hydrogen absorption-desorption processes with reasonable rate, thus the amorphous phase has the effect of generating nanostructured alloys by crystallization ${ }^{25}$. Alloys with nano-crystalline phases or a microstructure composed of nano-crystalline and amorphous phases exhibit higher rate of absorption-desorption kinetics at lower temperature in comparison with microcrystalline materials of the same composition $^{22}$.

The aim of the present work is to study the effect of alloying elements on $\mathrm{Mg}$ on the hydrogen absorptiondesorption behavior in different alloys produced by melt spinning, as described in the Table 1 . The effect of $\mathrm{Cu}$ and Si were studied in the $\mathrm{Mg}_{65} \mathrm{Cu}_{35}, \mathrm{Mg}_{90} \mathrm{Cu}_{10}$ and $\mathrm{Mg}_{90} \mathrm{Si}_{10}$, (at\%) alloys. The effect of $\mathrm{Al}$ and rare earths (using MM: mischmetal) were studied in the $\mathrm{Mg}_{65} \mathrm{Cu}_{25} \mathrm{Al}_{10}, \mathrm{Mg}_{65} \mathrm{Cu}_{25} \mathrm{MM}_{10}$ and $\mathrm{Mg}_{65} \mathrm{Cu}_{10} \mathrm{Al}_{15} \mathrm{MM}_{10}$ alloys. The $\mathrm{Mg}_{65} \mathrm{Cu}_{25} \mathrm{MM}_{10}$ alloy can be obtained in amorphous state by rapid solidification ${ }^{24}$. It is known that the addition of $\mathrm{Al}$ to pure $\mathrm{Mg}$ destabilizes the $\mathrm{MgH}_{2}$, and forms $\mathrm{Mg} / \mathrm{Al}$ alloys upon dehydrogenation. The $\mathrm{Mg}_{2} \mathrm{Si}$ phase is also attractive as a hydrogen storage material due to favorable desorption enthalpy $\left(\Delta H_{\text {desorption }}=36 \mathrm{~kJ} / \mathrm{mol}\right.$ $\mathrm{H}_{2}$ ) for room temperature operation.

Table 1: Alloys composition (at $\%$ )

\begin{tabular}{lc}
\hline Alloy & Alloy Composition (at\%) \\
\hline 1 & $\mathrm{Mg}_{90} \mathrm{Si}_{10}$ \\
2 & $\mathrm{Mg}_{90} \mathrm{Cu}_{10}$ \\
3 & $\mathrm{Mg}_{65} \mathrm{Cu}_{35}$ \\
4 & $\mathrm{Mg}_{65} \mathrm{Cu}_{25} \mathrm{Al}_{10}$ \\
5 & $\mathrm{Mg}_{65} \mathrm{Cu}_{25} \mathrm{MM}_{10}$ \\
6 & $\mathrm{Mg}_{65} \mathrm{Cu}_{10} \mathrm{Al}_{15} \mathrm{MM}_{10}$ \\
\hline
\end{tabular}

\section{Experimental}

Master alloy ingots with the chemical compositions $\mathrm{Mg}_{65} \mathrm{Cu}_{25} \mathrm{MM}_{10}$ and $\mathrm{Mg}_{65} \mathrm{Cu}_{10} \mathrm{Al}_{10} \mathrm{MM}_{10}$, were produced from pure elements by diffusion of filed $\mathrm{Cu}$ particles in a $\mathrm{Mg}-\mathrm{MM}$ or Mg-MM-Al molten alloy in a graphite crucible under Argon atmosphere in an electric furnace at $950^{\circ} \mathrm{C}$. The other master alloys were prepared by melting of pure elements in an induction furnace in a graphite crucible under argon atmosphere.

Melt spun samples were prepared under Argon atmosphere using a BN coated quartz tube. Continuous ribbons with 20-35 $\mu \mathrm{m}$ in thickness and $\sim 1 \mathrm{~mm}$ in width were obtained for MM containing alloys. Melt spun samples of the other alloys were obtained with thickness between 80-100 $\mu \mathrm{m}$ and $\sim 4 \mathrm{~mm}$ in width.

The characterization of the morphology of the melt spun samples has been carried out using a JEOL 6510 LV scanning electron microscope (SEM). The atomic structure of the as-spun and hydrogenated samples was characterized by X-ray diffraction using $\mathrm{Cu}$-Kalpha radiation. The thermal stability and the crystallization process of the melt-spun samples were studied by differential scanning calorimetry (DSC) at a heating rate of $20 \mathrm{~K} / \mathrm{min}$ under Argon flow. A complementary heat treatment at $360^{\circ} \mathrm{C}$ was performed to the $\mathrm{Mg}_{65} \mathrm{Cu}_{25} \mathrm{MM}_{10}$ and $\mathrm{Mg}_{65} \mathrm{Cu}_{10} \mathrm{Al}_{15} \mathrm{MM}_{10}$ alloys in order to analyse the phases in a complete crystallized state.

Hydrogen absorption-desorption tests were performed on the as-spun samples in a home-made Sieverts apparatus at $350^{\circ} \mathrm{C}$ and $2000 \mathrm{kPa}$ for the absorption and $150 \mathrm{kPa}$ for desorption. Both temperature and pressures used are the usual working parameters for pure $\mathrm{Mg}$ and many of its alloys $^{26,27}$. For the tests, each sample was carefully weighed and then inserted in a sample holder, fixing the holder onto the device and purging the whole system with three cycles of $120 \mathrm{kPa}$ hydrogen/vacuum. After this it was ready to start the tests. Under vacuum, the sample was isolated from the system and heated up to its operating temperature. When the sample reached the required temperature and maintaining the sample isolated, hydrogen was entered automatically in the system. Once at the set pressure, it was open the sample isolation valve and proceeded to record data.

\section{Results and discussion}

The surface of all ribbons (facing wheel and facing air) had typical morphologic features of samples produced by melt spinning. Figure 1(a) shows a secondary electrons (SE) image of facing wheel $\mathrm{Mg}_{90} \mathrm{Cu}_{10}$ ribbon where traces of roughness of the copper wheel and from bubbles trapped between the liquid and the copper wheel during the solidification process could be seen. Figure 1(b) shows a backscattered electrons (BSE) image of a cross section of the $\mathrm{Mg}_{90} \mathrm{Cu}_{10}$ as-spun sample where a dendritic morphology can be observed. Figure 1(c) and (d) show SE images of the $\mathrm{Mg}_{90} \mathrm{Si}_{10}$ as-spun sample, where in (c) typical ripples of the facing wheel of a melt spun sample are present; and in (d) an equiaxed grain structure on the surface facing the air can be observed.

Figures 2(a), (b), (c) and (d), show the X-ray diffractograms of the alloys $\mathrm{Mg}_{90} \mathrm{Cu}_{10}, \mathrm{Mg}_{65} \mathrm{Cu}_{35}, \mathrm{Mg}_{90} \mathrm{Si}_{10}$ and $\mathrm{Mg}_{65} \mathrm{Cu}_{25} \mathrm{Al}_{10}$, in the as-spun state and after hydrogen absorption-desorption cycles, respectively. In the binary $\mathrm{Mg}-\mathrm{Cu}$ alloys only stable equilibrium phases are observed in both states; $\mathrm{Mg}$ and $\mathrm{Mg}_{2} \mathrm{Cu}$ for $\mathrm{Mg}_{90} \mathrm{Cu}_{10}$ and $\mathrm{Mg}_{2} \mathrm{Cu}$ and $\mathrm{MgCu}_{2}$ for $\mathrm{Mg}_{65} \mathrm{Cu}_{35}$ alloy. In the $\mathrm{Mg}_{90} \mathrm{Si}_{10}$ alloy, also the stable phases are observed, $\mathrm{Mg}$ and $\mathrm{Mg}_{2} \mathrm{Si}$; in addition traces of the silicon oxide, $\mathrm{SiO}_{2}$ can be observed. The diffractograms of the ternary alloy, $\mathrm{Mg}_{65} \mathrm{Cu}_{25} \mathrm{Al}_{10}$, show the presence of the $\mathrm{Mg}$ and $(\mathrm{Cu}, \mathrm{Al})_{2} \mathrm{Mg}$ phases. No peaks related to hydrides and no new phases were observed in the diffractograms after the hydrogen absorption-desorption cycle for $\mathrm{Mg}_{90} \mathrm{Cu}_{10}, \mathrm{Mg}_{65} \mathrm{Cu}_{35}$ and $\mathrm{Mg}_{65} \mathrm{Cu}_{25} \mathrm{Al}_{10}$ alloys.

Figures 3(a) and (b) show the X-ray diffractograms of $\mathrm{Mg}_{65} \mathrm{Cu}_{25} \mathrm{MM}_{10}$ and $\mathrm{Mg}_{65} \mathrm{Cu}_{10} \mathrm{Al}_{15} \mathrm{MM}_{10}$ alloys in the as-spun state, after three cycles of hydrogen absorption-desorption and of the heat treated sample in a continue heating up to $360^{\circ} \mathrm{C}$.

The as-spun $\mathrm{Mg}_{65} \mathrm{Cu}_{25} \mathrm{MM}_{10}$ sample shows a typical X-ray difractogram of an amorphous structure with a broad peak at $2 \theta \sim 35.7^{\circ}$. The X-ray diffractograms after three cycles of hydrogen absorption-desorption show the $\mathrm{Mg}_{2} \mathrm{Cu}, \mathrm{MgH}_{2}$, $\mathrm{Mg}_{4} \mathrm{CuMM}$ phases. However, some peaks in the diffractograms could not be identified. The indexed phases after the heat treatment correspond to $\mathrm{Mg}_{2} \mathrm{Cu}$ and $\mathrm{Mg}_{4} \mathrm{CuMM}$ phases and the un-identified peaks present in the diffractogram after 


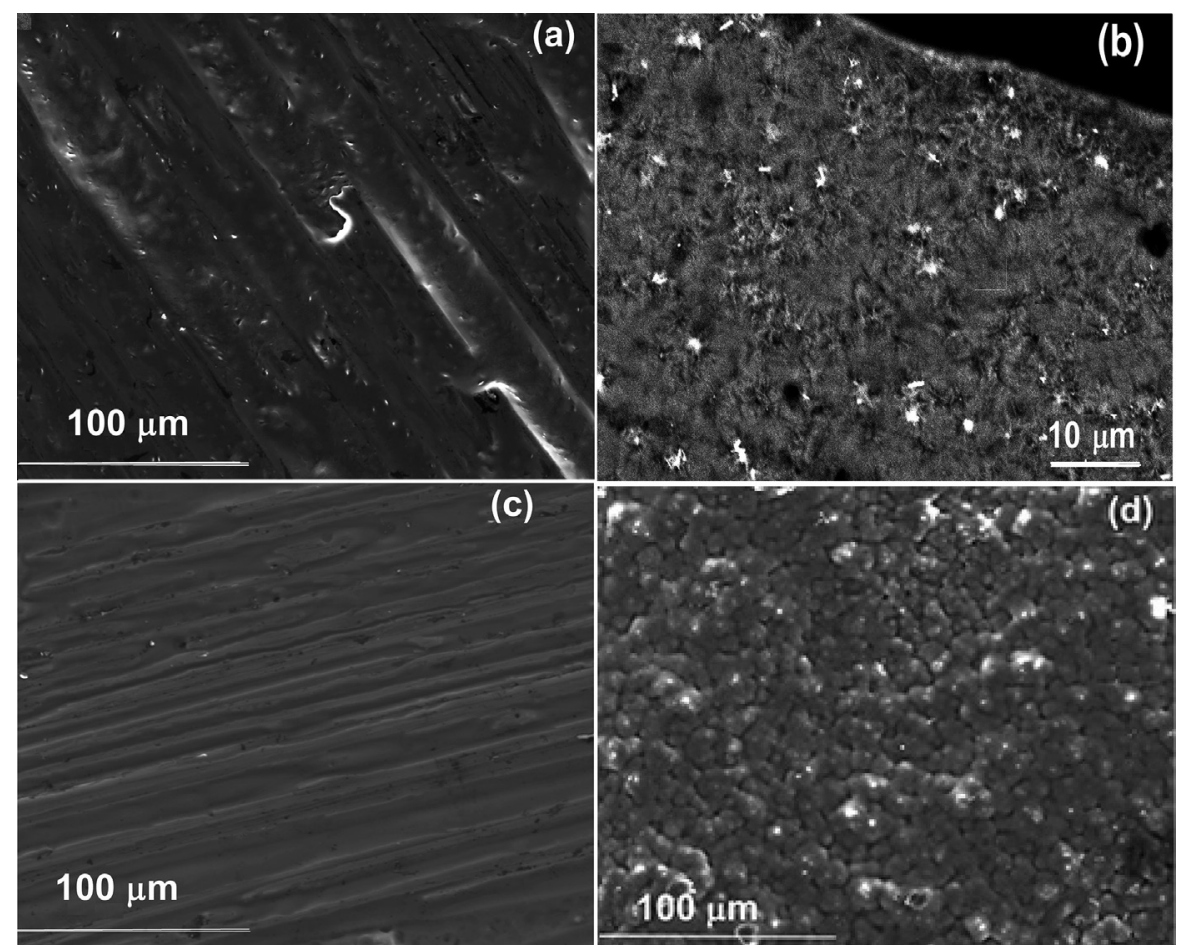

Figure 1: SEM micrographs of as-spun samples. (a) SE image facing wheel of the $\mathrm{Mg}_{90} \mathrm{Cu}_{10}$ sample; (b) BSE image of a cross section of the $\mathrm{Mg}_{90} \mathrm{Cu}_{10}$ sample; (c) SE facing wheel of the $\mathrm{Mg}_{90} \mathrm{Si}_{10}$ sample; (d) SE facing air of the $\mathrm{Mg}_{90} \mathrm{Si}_{10}$ sample.
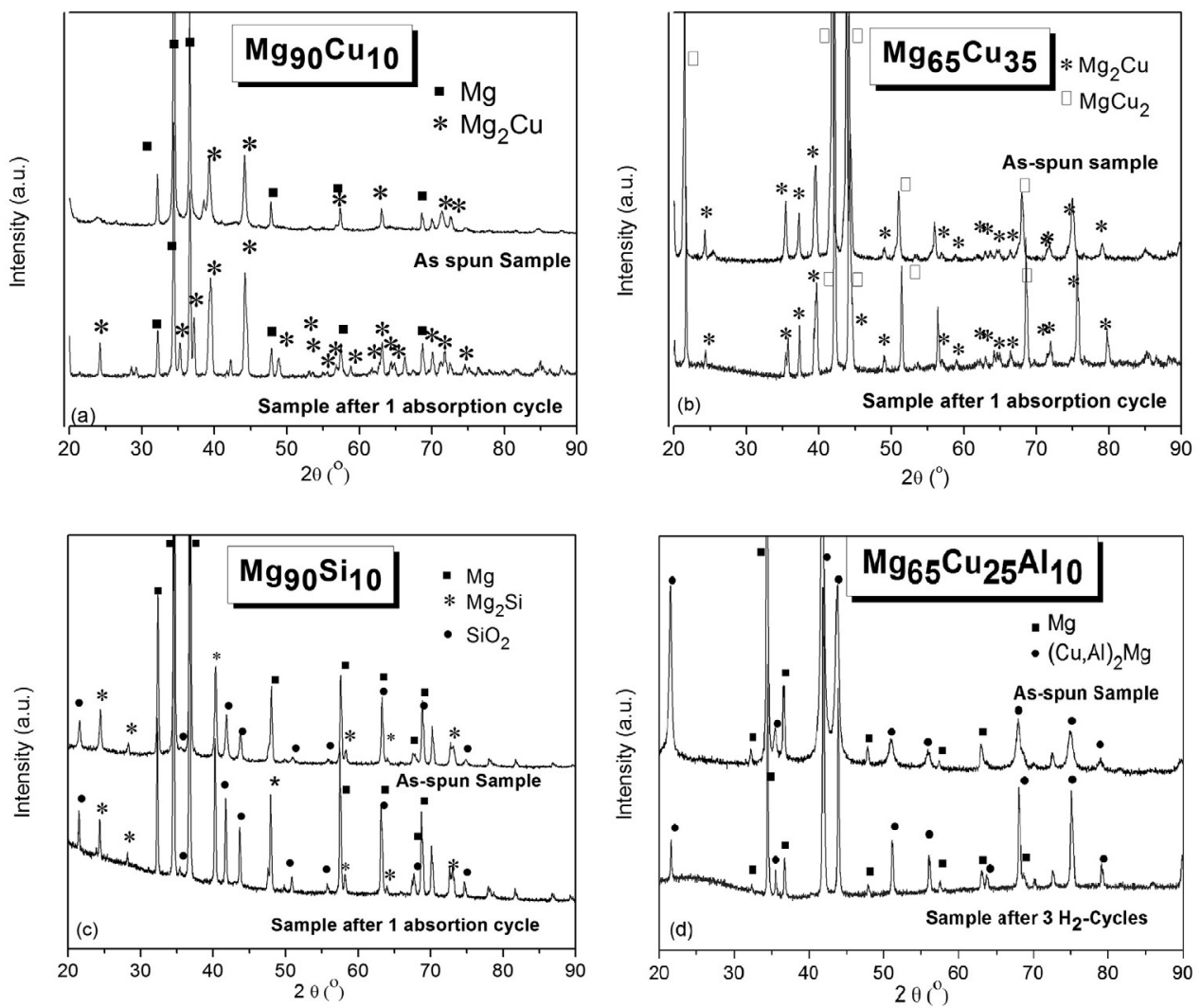

Figure 2: X-ray diffractograms of the as-spun samples and after hydrogen absorption-desorption cycles of the alloys: (a) $\mathrm{Mg}_{90} \mathrm{Cu}_{10}$, (b) $\mathrm{Mg}_{65} \mathrm{Cu}_{35}$ (c) $\mathrm{Mg}_{90} \mathrm{Si}_{10}$ and (d) $\mathrm{Mg}_{65} \mathrm{Cu}_{25} \mathrm{Al}_{10}$. 

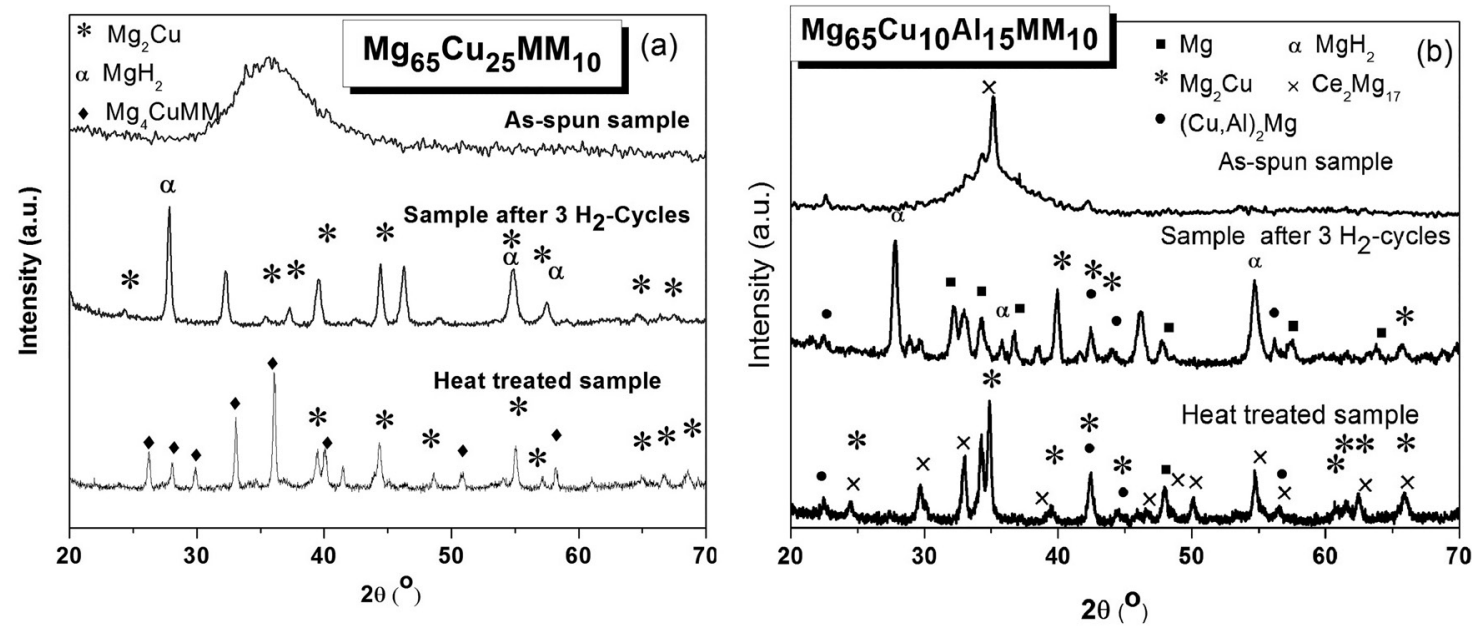

Figure 3: X-ray diffractograms of the as-spun, after three cycles of hydrogen absorption-desorption and of the heat treated samples in a continue heating up to $360^{\circ} \mathrm{C}$ of the alloys: (a) $\mathrm{Mg}_{65} \mathrm{Cu}_{25} \mathrm{MM}_{10}$, (b) $\mathrm{Mg}_{65} \mathrm{Cu}_{10} \mathrm{Al}_{15} \mathrm{MM}_{10}$.

hydrogen absorption-desorption cycles are not present, which suggests those could correspond to an hydride.

In the as-spun $\mathrm{Mg}_{65} \mathrm{Cu}_{10} \mathrm{Al}_{15} \mathrm{MM}_{10}$ sample the X-ray diffractogram shows a broad peak at $2 \theta \sim 34,7^{\circ}$ and some other peaks that could be indexed as corresponding to the $\mathrm{Mg}_{17} \mathrm{MM}_{2}$ phase. The microstructure at the as-spun state of this alloy would be composed of $\mathrm{Mg}_{17} \mathrm{MM}_{2}$ nanocrystals embedded in an amorphous matrix. These results suggest that the substitution of $15 \mathrm{at} \% \mathrm{Cu}$ by $\mathrm{Al}$ reduces the glass forming ability of the $\mathrm{Mg}_{65} \mathrm{Cu}_{25} \mathrm{MM}_{10}$ alloy. The identified phases in the X-ray diffractogram of the $\mathrm{Mg}-\mathrm{Cu}$-Al-MM sample after three cycles of hydrogen absorption-desorption are $\mathrm{Mg}$, $\mathrm{Mg}_{2} \mathrm{Cu},(\mathrm{Cu}, \mathrm{Al})_{2} \mathrm{Mg}, \mathrm{Mg}_{17} \mathrm{MM}_{2}$ and $\mathrm{MgH}_{2}$ also few peaks could not be identified, which are in the same $2 \theta$ position as observed before for the $\mathrm{Mg}_{65} \mathrm{Cu}_{25} \mathrm{MM}_{10}$ alloy. After the heat treatment up to $360^{\circ} \mathrm{C}$ of the as-spun sample the indexed phases in X-ray diffractogram are $\mathrm{Mg}_{2} \mathrm{Cu},(\mathrm{Cu}, \mathrm{Al})_{2} \mathrm{Mg}$, $\mathrm{Mg}_{17} \mathrm{MM}_{2}$ phases, and the un-identified peaks present in the diffractogram after hydrogen absorption-desorption cycles are not present, which again suggests those could correspond to an hydride remained in the cycled sample.

Figures 4(a) and (b) show DSC curves of as-spun amorphous $\mathrm{Mg}_{65} \mathrm{Cu}_{25} \mathrm{MM}_{10}$ and partially amorphous $\mathrm{Mg}_{65} \mathrm{Cu}_{10} \mathrm{Al}_{15} \mathrm{MM}_{10}$ samples. During heating the crystallization process consists of several steps for both alloys.

The crystallization process of the $\mathrm{Mg}_{65} \mathrm{Cu}_{25} \mathrm{MM}_{10}$ occurs in three steps. A first sharp exothermic peak at $\mathrm{Tp}_{1} \sim 170^{\circ} \mathrm{C}$ is followed by a second step with overlapped peaks that have an average peak temperature at $\mathrm{Tp}_{2} \sim 205^{\circ} \mathrm{C}$. Finally, the crystallization process ends with a third step with a sharp exothermic peak at $\mathrm{Tp}_{3} \sim 261^{\circ} \mathrm{C}$. The temperature of the first exothermal peak is $\sim 13^{\circ} \mathrm{C}$ lower than that obtained in the work of Murty et al. ${ }^{28}$, which is reasonable considering they used a higher heating speed $\left(40^{\circ} \mathrm{C} / \mathrm{min}\right)$ than in our work $\left(20^{\circ} \mathrm{C} / \mathrm{min}\right)$.

On the other hand, the crystallization process in the partially amorphous $\mathrm{Mg}_{65} \mathrm{Cu}_{10} \mathrm{Al}_{15} \mathrm{MM}_{10}$ alloy occurs in two exothermic steps with a first broad asymmetric peak at $\mathrm{T}_{\mathrm{p} 1} \sim 194^{\circ} \mathrm{C}$ and a second sharp peak at $\mathrm{T}_{\mathrm{p} 2} \sim 305^{\circ} \mathrm{C}$. The remained amorphous phase in the $\mathrm{Mg}_{65} \mathrm{Cu}_{10} \mathrm{Al}_{15} \mathrm{MM}_{10}$ is stable at higher temperature than the amorphous phase in the alloy without $\mathrm{Al}$, moreover the end of the crystallization process is shifted at higher temperature, few degrees below the test temperature $\left(350^{\circ} \mathrm{C}\right)$ used for the hydrogen absorptiondesorption cycles. Thus, the Al-containing alloy could develop a microstructure with a smaller grain size at $350^{\circ} \mathrm{C}$ during hydrogen cycles than the $\mathrm{Mg}_{65} \mathrm{Cu}_{25} \mathrm{MM}_{10}$.

The DSC curves obtained for the as-spun crystalline samples, $\mathrm{Mg}-\mathrm{Cu}, \mathrm{Mg}-\mathrm{Si}$ and $\mathrm{Mg}-\mathrm{Cu}-\mathrm{Al}$ alloys, did not showed any peak (solid state transformations), and are not showed in this work.

Figure 5 shows the hydrogen absorption curves of the $\mathrm{Mg}_{90} \mathrm{Cu}_{10}, \mathrm{Mg}_{65} \mathrm{Cu}_{35}, \mathrm{Mg}_{90} \mathrm{Si}_{10}$ and $\mathrm{Mg}_{65} \mathrm{Cu}_{25} \mathrm{Al}_{10}$ alloys. The binary alloys present an inert behaviour under hydrogenated atmosphere, doesn't show capacity for the absorbing reaction and hydrides formation at $350^{\circ} \mathrm{C}$ and $2000 \mathrm{kPa}$. However, the partial substitution of $10 \mathrm{at} \% \mathrm{Cu}$ by $\mathrm{Al}$ (ternary alloy $\mathrm{Mg}_{65} \mathrm{Cu}_{25} \mathrm{Al}_{10}$ ) shows a low hydrogen absorption capacity ( $\sim 1 \mathrm{wt} \% \mathrm{H}$ after $2 \mathrm{hs} 15 \mathrm{~min})$. The low absorption rate could correspond to: a low fraction of free $\mathrm{Mg}$ in the alloy to form hydride and/or some barrier in the sample surface that prevents the diffusion of hydrogen into the volume of the sample. Krozer et al. and Luz et al. ${ }^{29,30}$ explain this phenomenon due to a dense surface layer of hydrides which do not allow the diffusion of hydrogen in the sample.

Figures 6 (a), (b) and (c) show the activation, second and third cycle of hydrogen absorption for the $\mathrm{Mg}_{65} \mathrm{Cu}_{25} \mathrm{MM}_{10}$ and $\mathrm{Mg}_{65} \mathrm{Cu}_{10} \mathrm{Al}_{15} \mathrm{MM}_{10}$ alloys respectively. Figures 7(a), (b) and (c) show the activation, second and third cycle of hydrogen desorption as function of the time for $\mathrm{Mg}_{65} \mathrm{Cu}_{25} \mathrm{MM}_{10}$ and $\mathrm{Mg}_{65} \mathrm{Cu}_{10} \mathrm{Al}_{15} \mathrm{MM}_{10}$ alloys respectively. These alloys were tested to three consecutive cycles of hydrogen absorptiondesorption. It was found that the rate of the first absorption cycle (activation) is low, which is usual for Mg alloys ${ }^{31}$. The sluggish rate during the activation cycle can be related to the presence of an oxide layer on the surface of the sample, which must be broken to start the hydrogenation through the volume of the material ${ }^{4}$. The Al-containing alloy shows a harder activation process than the $\mathrm{Mg}_{65} \mathrm{Cu}_{25} \mathrm{MM}_{10}$ alloy; however, once the hydrogenation is activated the absorption 

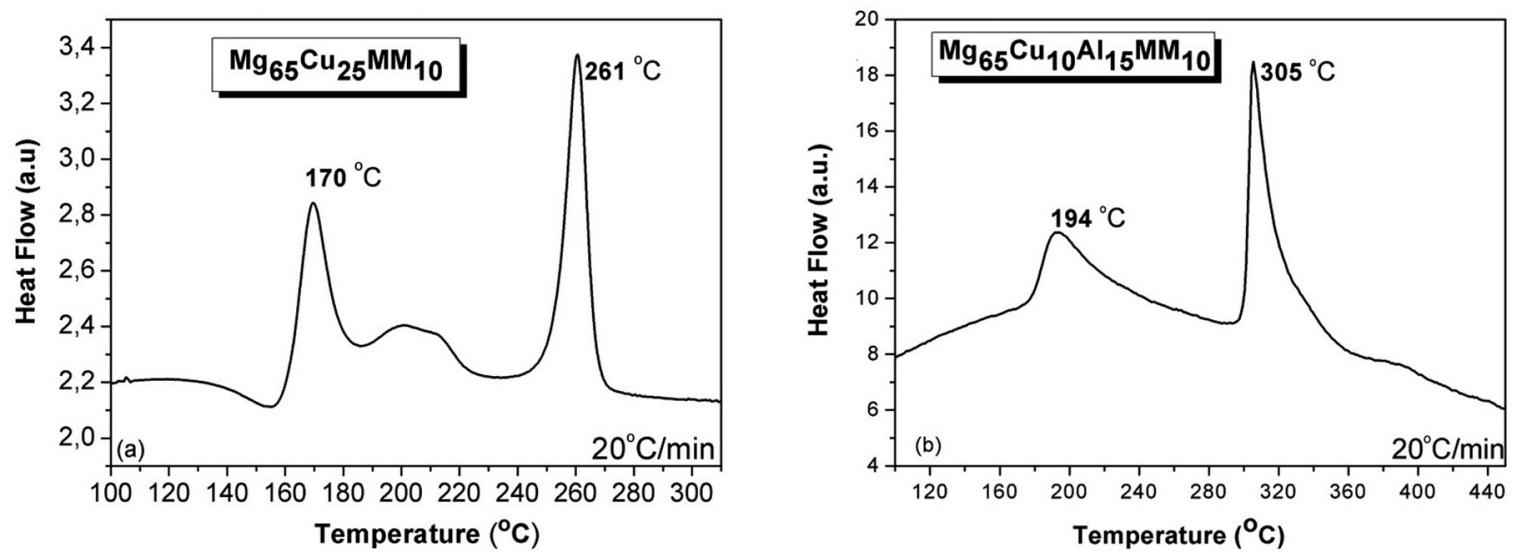

Figure 4: DSC curves of the as-spun $\mathrm{Mg}_{65} \mathrm{Cu}_{25} \mathrm{MM}_{10}$ and $\mathrm{Mg}_{65} \mathrm{Cu}_{10} \mathrm{Al}_{15} \mathrm{MM}_{10}$ samples.

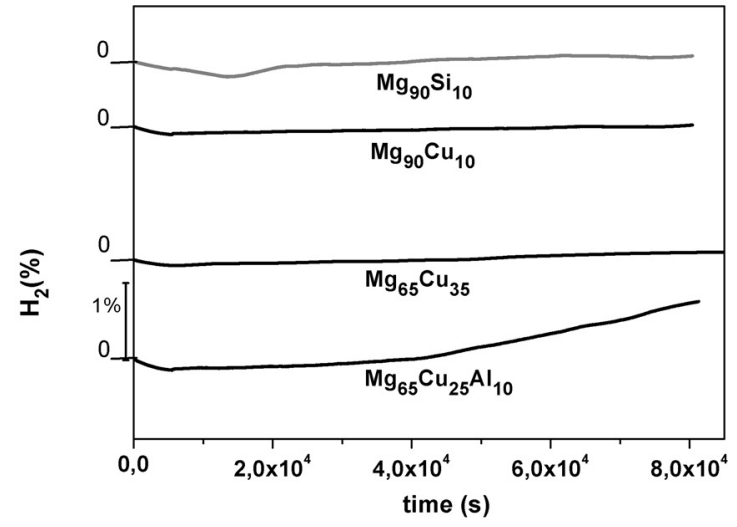

Figure 5: Absorption kinetics at $350^{\circ} \mathrm{C}$ and $2000 \mathrm{kPa}$ of $\mathrm{Mg}_{90} \mathrm{Cu}_{10}$, $\mathrm{Mg}_{65} \mathrm{Cu}_{35}, \mathrm{Mg}_{90} \mathrm{Si}_{10}$ and the $\mathrm{Mg}_{65} \mathrm{Cu}_{25} \mathrm{Al}_{10}$ samples.

rate and capacities in the second and third cycles are higher than in the $\mathrm{Mg}_{65} \mathrm{Cu}_{25} \mathrm{MM}_{10}$ alloy. Thus, the absorption time to reach the hydrogen saturation in the second and third cycle for $\mathrm{Mg}_{65} \mathrm{Cu}_{10} \mathrm{Al}_{15} \mathrm{MM}_{10}$ alloy is lower than for the $\mathrm{Mg}_{65} \mathrm{Cu}_{25} \mathrm{MM}_{10}$ alloy. The absorption time is observed to decrease from the second to the third cycle for both alloys, which is in agreement with a general behaviour of $\mathrm{H}$-sorption properties in $\mathrm{Mg}$ alloys ${ }^{31,32}$.

The partial substitution of $\mathrm{Cu}$ by $\mathrm{Al}$ in the $\mathrm{Mg}_{65} \mathrm{Cu}_{25} \mathrm{MM}_{10}$ appears to enhance the kinetic of the hydrogen absorption at $350^{\circ} \mathrm{C}$ and $2000 \mathrm{kPa}$.

The hydrogen desorption behavior of $\mathrm{Mg}_{65} \mathrm{Cu}_{25} \mathrm{MM}_{10}$ and $\mathrm{Mg}_{65} \mathrm{Cu}_{10} \mathrm{Al}_{15} \mathrm{MM}_{10}$ alloys can be analyzed from the curves shown in Figure 7. No incubation time is observed for hydrogen desorption at $350^{\circ} \mathrm{C}$ and $150 \mathrm{kPa}$. The desorption rate is faster than the absorption rate for both alloys. There is also observed that the desorption time for the Al-containing alloy during the second cycle is $\sim 100 \mathrm{~s}$ while this time is $\sim 600 \mathrm{~s}$ for the $\mathrm{Mg}_{65} \mathrm{Cu}_{25} \mathrm{MM}_{10}$ alloy, both times are shorter than for the first cycle. Then, the desorption time is further reduced for the third cycle. This behavior is in agreement with what was observed by other authors; the presence of Al destabilizes $\mathrm{Mg}$ hydrides and consequently increases
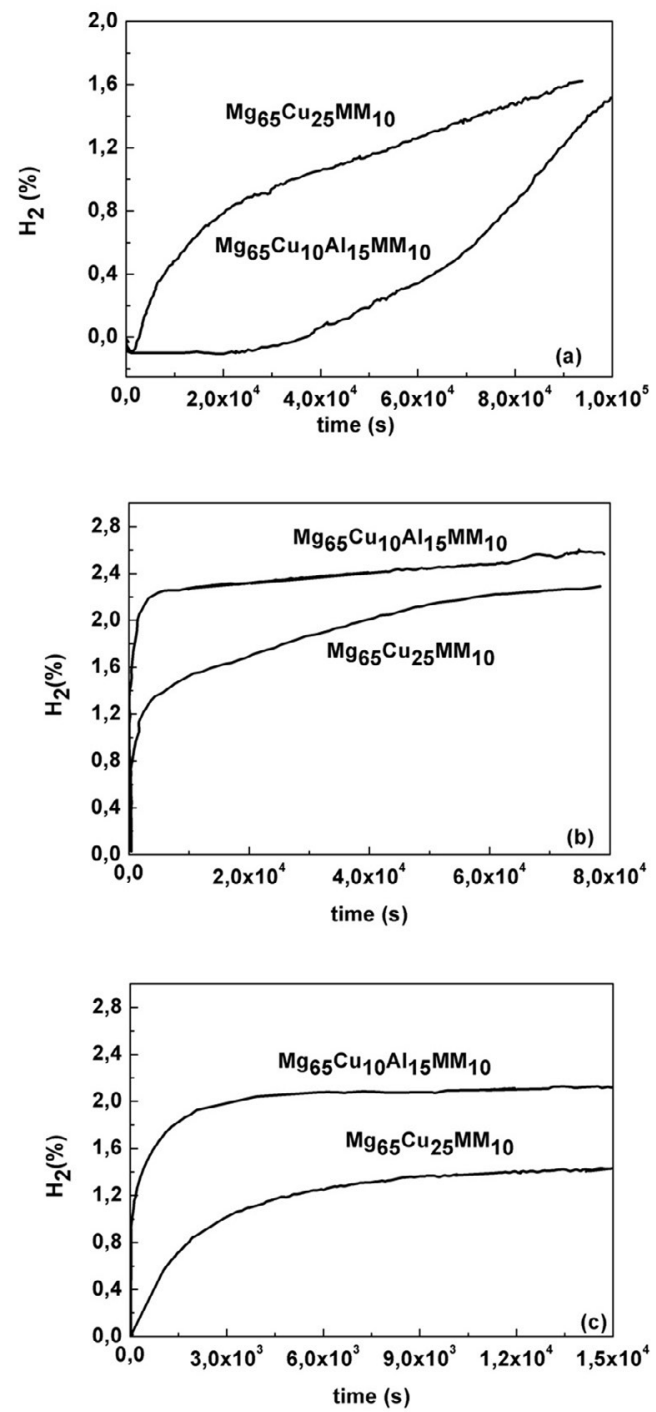

Figure 6: Absorption kinetic at $350^{\circ} \mathrm{C}$ and $2000 \mathrm{kPa}$ of the $\mathrm{Mg}_{65} \mathrm{Cu}_{25} \mathrm{MM}_{10}$ and $\mathrm{Mg}_{65} \mathrm{Cu}_{10} \mathrm{Al}_{15} \mathrm{MM}_{10}$ alloy; (a) first cycle (activation); (b) second cycle, and (c) third cycle. 

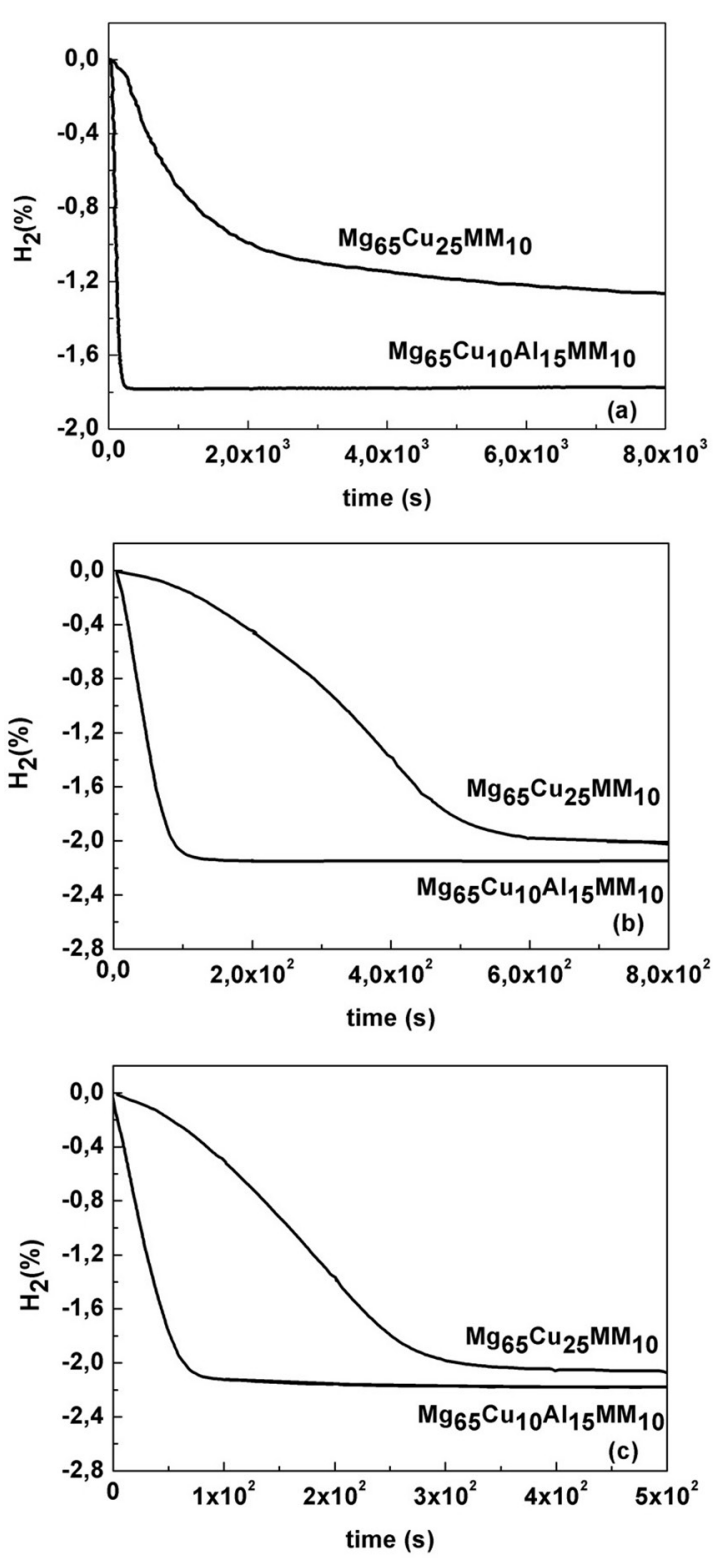

Figure 7: Desorption kinetic at $350^{\circ} \mathrm{C}$ and $150 \mathrm{kPa}$ of the $\mathrm{Mg}_{65} \mathrm{Cu}_{25} \mathrm{MM}_{10}$ and $\mathrm{Mg}_{65} \mathrm{Cu}_{10} \mathrm{Al}_{15} \mathrm{MM}_{10}$ alloy (a) first cycle (activation); (b) second cycle, and (c) third cycle.

the desorption kinetics ${ }^{4,33}$. J. Lang et al. ${ }^{34}$ studied kinetics of absorption and desorption for $\mathrm{Mg}$ and $\mathrm{Mg}$ hydrides on cold rolled samples, and they found that the cold rolling process produces a reduction of the crystal size (tens of $\mathrm{nm}$ ), that improves the H-sorption properties, similarly as the results obtained in this work on samples produced by rapid solidification. The subsequent nano-crystallization from the amorphous phase occurs during the activation cycle at $350^{\circ} \mathrm{C}$.

The rapid solidification produces amorphous and/or nano-crystalline phases that lead to the same beneficial effect that the cold rolling process on the $\mathrm{H}$-sorption behaviour.

A reduction of the $\mathrm{H}_{2}$ capacities between the second and third cycle is observed for both alloys. This reduction is near $40 \%$ for $\mathrm{Mg}_{65} \mathrm{Cu}_{25} \mathrm{MM}_{10}$ and only $20 \%$ for $\mathrm{Mg}_{65} \mathrm{Cu}_{10} \mathrm{Al}_{15} \mathrm{MM}_{10}$.
This shows that the $\mathrm{Al}$ addition also improves the reversibility of the $\mathrm{Mg}_{65} \mathrm{Cu}_{25} \mathrm{MM}_{10}$ alloy. This behaviour can be explained taking into account that $\mathrm{Al}$ destabilizes the $\mathrm{MgH}_{2}^{4,33}$ increasing the amount of reversible hydrides.

Considering that an alloy absorbs two hydrogen atoms like $\mathrm{MgH}_{2}$ per each $\mathrm{Mg}$ atom in the alloy, from the atomic mass of each composition it can obtain a maximum theoretical hydrogen storage capacity. For $\mathrm{Mg}_{65} \mathrm{Cu}_{25} \mathrm{MM}_{10}$ and $\mathrm{Mg}_{65} \mathrm{Cu}_{10} \mathrm{Al}_{15} \mathrm{MM}_{10}$ alloys these values are $4.2 \mathrm{wt} \% \mathrm{H}$ and $4.6 \mathrm{wt} \% \mathrm{H}$ respectively. For the studied samples, it is observed from Figure 6 that in the second cycle the capacities are $2.3 \mathrm{wt} \% \mathrm{H}$ for $\mathrm{Mg}_{65} \mathrm{Cu}_{25} \mathrm{MM}_{10}$ and $2.6 \mathrm{wt} \% \mathrm{H}$ for $\mathrm{Mg}_{65} \mathrm{Cu}_{10} \mathrm{Al}_{15} \mathrm{MM}_{10}$; while for the third cycle these values are $1.4 \mathrm{wt} \% \mathrm{H}$ and $2.2 \mathrm{wt} \% \mathrm{H}$ respectively.

The partial substitution of $\mathrm{Cu}$ by $\mathrm{MM}$ or/and by $\mathrm{Al}$ in $\mathrm{Mg}_{65} \mathrm{Cu}_{35}$ alloy promotes the formation of hydrides and improve the $\mathrm{H}$-sorption properties of the $\mathrm{Mg}_{65} \mathrm{Cu}_{35}$ alloy as shown in Figure 3, 6 and 7. The X-ray diffractograms of both $\mathrm{Mg}_{65} \mathrm{Cu}_{25} \mathrm{MM}_{10}$ and $\mathrm{Mg}_{65} \mathrm{Cu}_{10} \mathrm{Al}_{15} \mathrm{MM}_{10}$ alloys after the third hydrogenation-dehydrogenation cycle confirm the formation of $\alpha$-hydride $\mathrm{MgH}_{2}$.

Finally, it is observed that the simultaneous partial substitution of $\mathrm{Cu}$ by both $\mathrm{Al}$ and $\mathrm{MM}$ in the $\mathrm{Mg}_{65} \mathrm{Cu}_{35}$ alloy produced by rapid solidification yields an excellent improvement in the $\mathrm{H}$-sorption properties.

\section{Conclusion}

From the hydrogen absorption and desorption tests carried out at $350^{\circ} \mathrm{C}$ and $2000 \mathrm{kPa}$ and at $350^{\circ} \mathrm{C}$ and 150 $\mathrm{kPa}$ respectively, the following effects were demonstrated:

- $\mathrm{Cu}$ and Si reduce the hydrogen absorption capacity of $\mathrm{Mg}$ in the $\mathrm{Mg}_{90} \mathrm{Si}_{10}, \mathrm{Mg}_{90} \mathrm{Cu}_{10}$ and $\mathrm{Mg}_{65} \mathrm{Cu}_{35}$ alloys;

- The partial substitution of $10 \% \mathrm{Cu}$ by $\mathrm{Al}$ in the $\mathrm{Mg}_{65} \mathrm{Cu}_{35}$ improves the hydrogen activation; while the partial substitution of $10 \% \mathrm{Cu}$ by $\mathrm{MM}$ has stronger effect on activation;

- Finally the alloy containing MM and Al, $\mathrm{Mg}_{65} \mathrm{Cu}_{10} \mathrm{Al}_{15} \mathrm{MM}_{10}$, has the best behaviour for hydrogen absorption-desorption process. This alloy has higher absorption-desorption kinetic reactions and better reversibility than both ternary alloys, $\mathrm{Mg}_{65} \mathrm{Cu}_{25} \mathrm{Al}_{10}$ and $\mathrm{Mg}_{65} \mathrm{Cu}_{25} \mathrm{MM}_{10}$;

- The addition of Rare Earths and $\mathrm{Al}$ together in $\mathrm{Mg}$ base alloys can be used to design new Mg alloys with improved hydrogen absorption-desorption kinetics and reversibility.

\section{Acknowledgments}

This work was partially funded by the PICT-Oxford 2010/2831 and the UBACYT 2014/20020130100663. The authors thank Dr. Daniel Vega for taken some of the X-ray diffractograms used in this work.

\section{References}

1. Sakintuna B, Lamari-Darkrim F, Hirscher M. Metal hydride materials for solid hydrogen storage: A review. International Journal of Hydrogen Energy. 2007;32(9):1121-1140. 
2. Ogden JM. Developing an infrastructure for hydrogen vehicles: a Southern California case study. International Journal of Hydrogen Energy. 1999;24(8):709-730.

3. Vojtěch D, Guhlová P, Mort’aniková M, Janík P. Hydrogen storage by direct electrochemical hydriding of Mg-based alloys. Journal of Alloys and Compounds. 2010;494:456-462.

4. Jain IP, Lal C, Jain A. Hydrogen storage in Mg: A most promising material. International Journal of Hydrogen Energy. 2010;35(10):5133-5144.

5. Reilly J Jr, Wiswall RH Jr. Reaction of hydrogen with alloys of magnesium and copper. Inorganic Chemistry. 1967;6(12):22202223.

6. Reilly J Jr, Wiswall RH Jr. Reaction of hydrogen with alloys of magnesium and nickel and the formation of $\mathrm{Mg} 2 \mathrm{NiH} 4$. Inorganic Chemistry. 1968;7(11):2254-2256.

7. Tanguy B, Soubeyroux JL, Pezat M, Portier J, Hagenmuller P. Amelioration des conditions de synthese de l'hydrure de magnesium a l'aide d'adjuvants. Materials Research Bulletin. 1976;11(11):1441-1447.

8. Bogdanović B, Hartwig TH, Spliethoff B. The development, testing and optimization of energy storage materials based on the $\mathrm{MgH} 2 \mathrm{Mg}$ system. International Journal of Hydrogen Energy. 1993;18(7):575-589.

9. Huot J, Liang G, Schulz R. Mechanically alloyed metal hydride systems. Applied Physics A. 2001;72(2):187-195.

10. Oelerich W, Klassen T, Bormann R. Metal oxides as catalysts for improved hydrogen sorption in nanocrystalline Mg-based materials. Journal of Alloys and Compounds. 2001;315(12):237-242.

11. Kalisvaart WP, Niessen RAH, Notten PHL. Electrochemical hydrogen storage in MgSc alloys: A comparative study between thin films and bulk materials. Journal of Alloys and Compounds. 2006;417(1-2):280-291.

12. Miyaoka H, Ichikawa T, Kojima Y. The reaction process of hydrogen absorption and desorption on the nanocomposite of hydrogenated graphite and lithium hydride. Nanotechnology. 2009;20(20):204016.

13. Ha W, Lee HS, Youn JI, Hong TW, Kim YJ. Hydrogenation and degradation of $\mathrm{Mg}-10 \mathrm{wt} \% \mathrm{Ni}$ alloy after cyclic hydridingdehydriding. International Journal of Hydrogen Energy. 2007;32(12):1885-1889.

14. Gu H, Zhu Y, Li L. Hydrogen storage properties of Mg-30 wt.\% LaNi5 composite prepared by hydriding combustion synthesis followed by mechanical milling (HCS + MM). International Journal of Hydrogen Energy. 2009;34(3):1405-1410.

15. Xiao X, Liu G, Peng S, Yu K, Li S, Chen C, et al. Microstructure and hydrogen storage characteristics of nanocrystalline $\mathrm{Mg}+\mathrm{x}$ $\mathrm{wt} \% \mathrm{LaMg} 2 \mathrm{Ni}(\mathrm{x}=0-30)$ composites. International Journal of Hydrogen Energy. 2010;35(7):2786-2790.

16. Schlapbach L, Züttel A. Hydrogen-storage materials for mobile applications. Nature. 2001;414:353-358.

17. Varin RA, Czujko T, Wronski ZS. Nanomaterials for solid state hydrogen storage. New York: Springer; 2009.

18. Nowak M, Okonska I, Smardz L, Jurczyk M. Segregation Effect on Nanoscale Mg - Based Hydrogen Storage Materials. Materials Science Forum. 2009;610-613:431-440.
19. Shao H, Ma WG, Kohno M, Takata Y, Xin GB, Fujikawa S, et al. Hydrogen storage and thermal conductivity properties of Mg-based materials with different structures. International Journal of Hydrogen Energy. 2014;39(18):9893-9898.

20. Jurczyk M, Nowak M, Szajek A, Jezierski A. Hydrogen storage by $\mathrm{Mg}$-based nanocomposites. International Journal of Hydrogen. 2012;37(4):3652-3658.

21. Au M. Hydrogen storage properties of magnesium based nanostructured composite materials. Materials Science and Engineering: B. 2005;117(1):37-44.

22. Zhang Y, Wang H, Zhai T, Yang T, Qi Y, Zhao D. Hydrogen storage characteristics of the nanocrystalline and amorphous $\mathrm{Mg}-\mathrm{Nd}-$ $\mathrm{Ni}-\mathrm{Cu}$-based alloys prepared by melt spinning. International Journal of Hydrogen Energy. 2014;39(8):3790-3798.

23. Bouaricha S, Dodelet JP, Guay D, Huot J, Boily S, Schulz R. Hydriding behavior of $\mathrm{Mg}-\mathrm{Al}$ and leached $\mathrm{Mg}-\mathrm{Al}$ compounds prepared by high-energy ball-milling. Journal of Alloys and Compounds. 2000;297(1-2):282-293.

24. Inoue A. Bulk Amorphous Alloys - Preparation and Fundamental Characteristics. Materials Science Foundations, vol. 4, Aedermannsdorf: TransTech; 1998. 124p.

25. Spassov T, Köster U. Thermal stability and hydriding properties of nanocrystalline melt-spun $\mathrm{Mg}_{63} \mathrm{Ni}_{30} \mathrm{Y}_{7}$ alloy. Journal of Alloys and Compounds. 1998;279(2):279-286.

26. Jain P, Lang J, Skryabina NY, Fruchart D, Santos SF, Binder K, et al. $\mathrm{MgH} 2$ as dopant for improved activation of commercial Mg ingot. Journal of Alloys and Compounds. 2013;575:364-369.

27. Amira S, Huot J. Effect of cold rolling on hydrogen sorption properties of die-cast and as-cast magnesium alloys. Journal of Alloys and Compounds. 2012;520:287-294.

28. Murty BS, Hono K. Formation of Nanocrystalline Particles in Glassy Matrix in Melt-Spun Mg--Cu--Y Based Alloys. Materials Transactions. 2000;41(11):1538-1544.

29. Krozer A, Kasemo B. Equilibrium hydrogen uptake and associated kinetics for the Mg-H2 system at low pressures. Journal of Physics: Condensed Matter. 1989;1(8):1533-1538.

30. Luz Z, Genossar J, Rudman PS. Identification of the diffusing atom in MgH2. Journal of the Less Common Metals. 1980;73(1):113-118.

31. Kalisvaart WP, Harrower CT, Haagsma J, Zahiri B, Luber EJ, Ophus C, et al. Hydrogen storage in binary and ternary Mgbased alloys: A comprehensive experimental study. International Journal of Hydrogen Energy. 2010;35(5):2091-2103.

32. Lass EA. Hydrogen storage measurements in novel Mg-based nanostructured alloys produced via rapid solidification and devitrification. International Journal of Hydrogen Energy. 2011;36(17):10787-10796.

33. Crivello JC, Nobuki T, Kuji T. Improvement of Mg-Al alloys for hydrogen storage applications. International Journal of Hydrogen Energy. 2009;34(4):1937-1943.

34. Lang J, Skryabina N, Fruchart D, Danaie M, Huot J. Microstructure of Cold Rolled Magnesium and Magnesium Hydrides for Hydrogen Storage Applications. Chemistry for Sustainable Development. 2013;21:545-552. 